\title{
PLANTS ACCUMULATING HEAVY METALS IN THE SUDETY MTS
}

\author{
TERESA BREJ, JERZY FABISZEWSKI \\ Department of Botany and Plant Ecology \\ Agricultural University \\ Cybulskiego 32, 50-205 Wrocław, Poland \\ e-mail: tbrej@ozi.ar.wroc.pl
}

(Received: September 19, 2005. Accepted: October 19, 2005)

\begin{abstract}
The Sudeten flora consists of some plants we can recognize as heavy metal accumulators. Between others there are: Thlaspi caerulescens, Arabidopsis halleri, Armeria maritima ssp. halleri s.l. and probably the endemic fern Asplenium onopteris var. silesiaca. The authors present the concentrations of some important heavy metals measured in aboveground plant dry weight. The highest concentration of zinc was $8220 \mathrm{ppm}$ (Thlaspi), nickel -3100 ppm (Thlaspi), lead - 83 ppm (Armeria), copper - 611 ppm (Arabidopsis) and cadmium - 28 ppm (Thlaspi). The concentrations depend rather on species or population specification than on ore deposit quality. There are no typical hyperaccumulator among plants we have examined, but some signs of hyperaccumulation of nickel, zinc and lead could be observed. There are no typical endemic taxa, only Asplenium onopteris var. silesiaca and Armeria maritima ssp. halleri may be recognized as neoendemic taxa, but still of unclear systematic position. During the study we tried to find out why some Sudeten vascular plants do not develop heavy metals hyperaccumulation and why they are rather latent hyperaccumulators. Finally, we suggest to protect some metallicolous areas in spite they are rather territories with low plant biodiversity.
\end{abstract}

KEY WORDS: the Sudety Mts, hyperaccumulators, latent hyperaccumulation, Asplenium onopteris var. silesiaca, Silene vulgaris ssp. humilis, Thlaspi caerulescens, Arabidopsis halleri, Armeria maritima ssp. halleri.

\section{INTRODUCTION}

Flower plants are characterized by a differentiated capability to take up and accumulate heavy metals. Among ecologists and physiologists the greatest interest evoke species, the so-called hyperaccumulators, taking up and accumulating selected metals in considerable amounts in relation to their total biomass. The capability of these plants to an increased accumulation is variable, according to the uptake of metallic elements. Thus, according to the opinions of many authors, as hyperaccumulators recognized are such plant species, which accumulate in tissues of aboveground organs more than $0.1 \%(100 \mathrm{ppm})$ in dry mass of nickel, cobalt, copper, lead and chrome - and also plants in dry mass of which more than $1 \%(10000 \mathrm{ppm})$ of zinc or manganese was recorded (Baker and Brooks 1989; Brooks 1998). The cited ranges of contents do not make absolute limits and are only conventional concentrations, originating from metal-content measurements in plants known as typical, endemic metalophytes. However, one should have regard to the fact, that in water cultures and other artificial conditions, experimental plants may take up and accumula- te much greater amounts of metals, and on that basis the natural limits of accumulation cannot be determined. Among about 400 plant species - heavy metals hyperaccumulators - only a dozen occurs in Central and Southern Europe (Ernst 1974, 1976). Most of them form floras characteristic for soils containing very high amounts of metals in distant areas, like Africa, Cuba, New Caledonia, Brazil and California. These exotic species form usually endemic floras (Roberts and Proctor 1992; Brooks 1998).

There are no typical hyperaccumulators in the flora of Poland and Silesia, but one can meet species taking up and accumulating more heavy metals than the other accompanying them plants. Those plants, like in other areas, occur either on soils abundant by nature in heavy metals (e.g. serpentine soils), or in territories, which secondarily have been enriched with metals because of mans' activity (e.g. territories around industrial plants emitting metals, old excavation heaps, etc.). The natural metal-bearing areas are those, confined in Poland and Silesia to few calamine-, and other ore-bearing territories (e.g. near Olkusz, Miedzianka, Złoty Stok), and the scarce, specific exclusively to Lower Silesia, serpentinous soils (Sudeten Foothills, certain ran- 

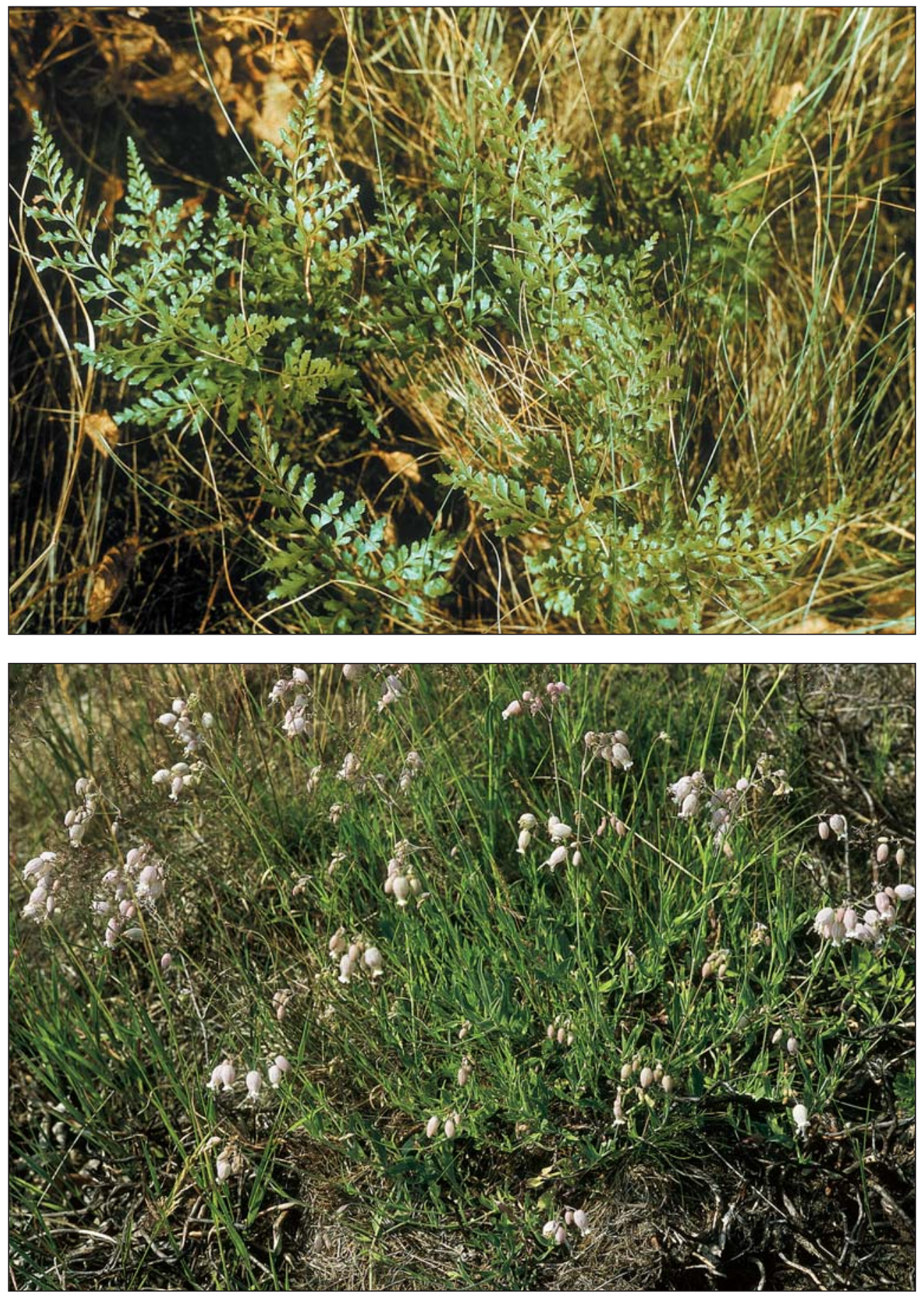

Fig. 1. Asplenium onopteris var. silesiaca. ges of the Sudety proper). Both in territories metallic by nature, or in areas with anthropogenically raised contents of heavy metals, one does not meet in the territory of Poland with high, known only in typical hyperaccumulators, contents of elements (Fabiszewski et al. 1983; Fabiszewski 1986; Godzik 1991, 1993). Nevertheless, several naturally occurring species show properties nearing the hyperaccumulators, but in any case, one can recognize them as regional (local) hyperaccumulators. Since it was proved that hyperaccumulation shows adaptation capabilities (Shaw 1990; Boyd and Martens 1998) in non-metallic soils, then in conditions of raised contents of metals, this phenomenon develops in a continuous way. Hence, the thesis can be submitted, that species or "ecotypes" connected to metalbearing terrains may be in the pre-adaptation period and show a potential capability to hyperaccumulation, which only periodically is shared by the so-called latent hyperaccumulators*) according to Boyd and Martens (1992, 1998). Thus, it is only a question of time before accumulation develops "fully", or it is already sufficient and concordant with needs of those plants in the given soil conditions. This run of reasoning is confirmed by Ernst's (1997) investigations, who stated that the concentration of 400 ppm of copper in tissues of Silene vulgaris, occurring on metal-bearing soil, made a sufficiently toxic dose for larvae feeding on the plant. The so-called defensive hypothesis, presenting the relation between accumulation of metals and reaction of pathogens is, of course, only a probable supposition confirming the phenomenon of existence of potential (latent) accumulators.

\footnotetext{
* The term partly connected with qualification by Ernst (1974)
} 


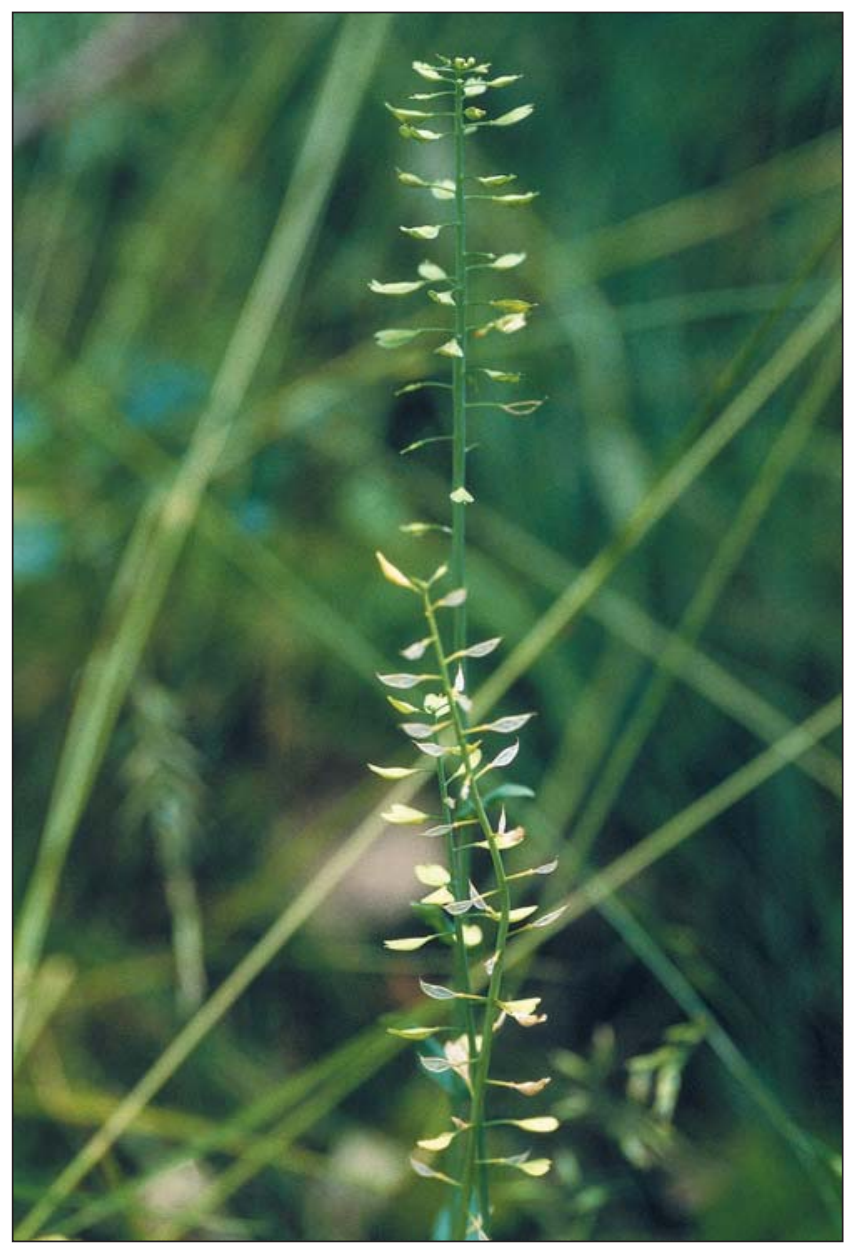

Fig. 3. Thlaspi caerulescens.

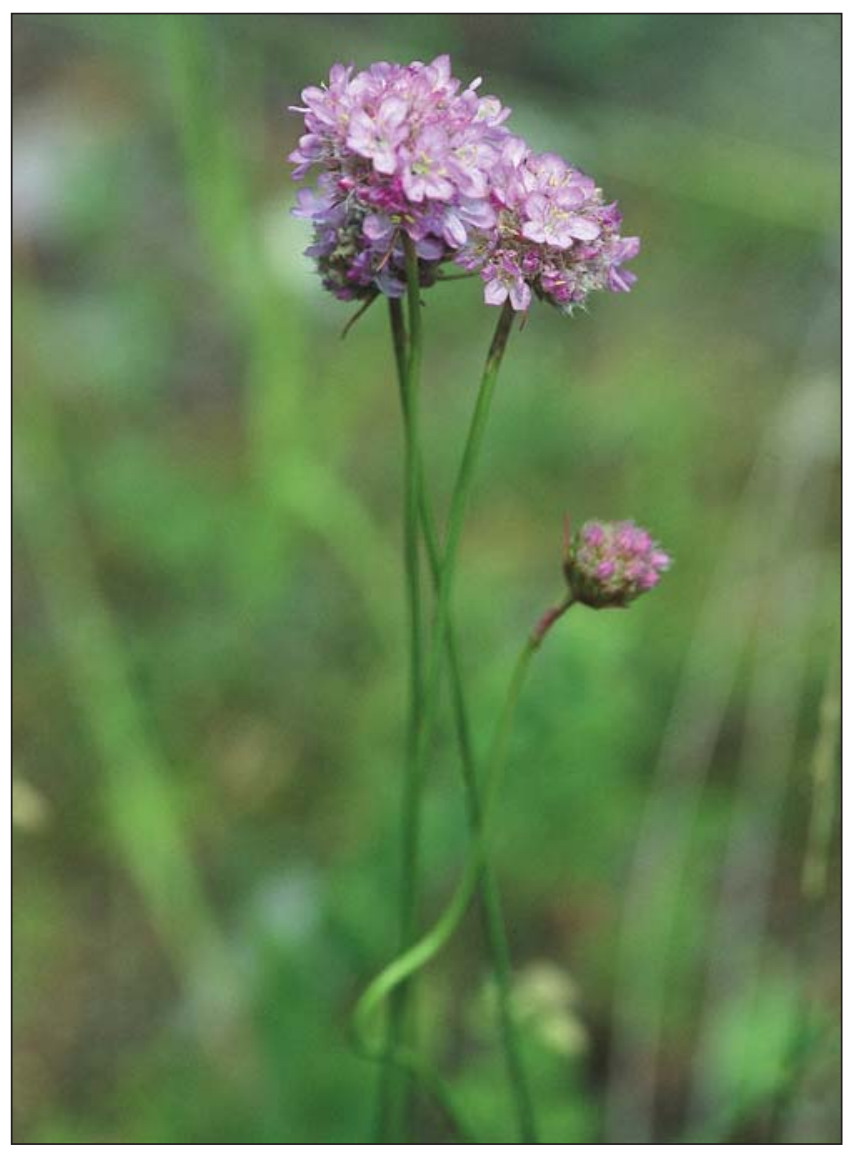

Fig. 5. Armeria maritima ssp. halleri.

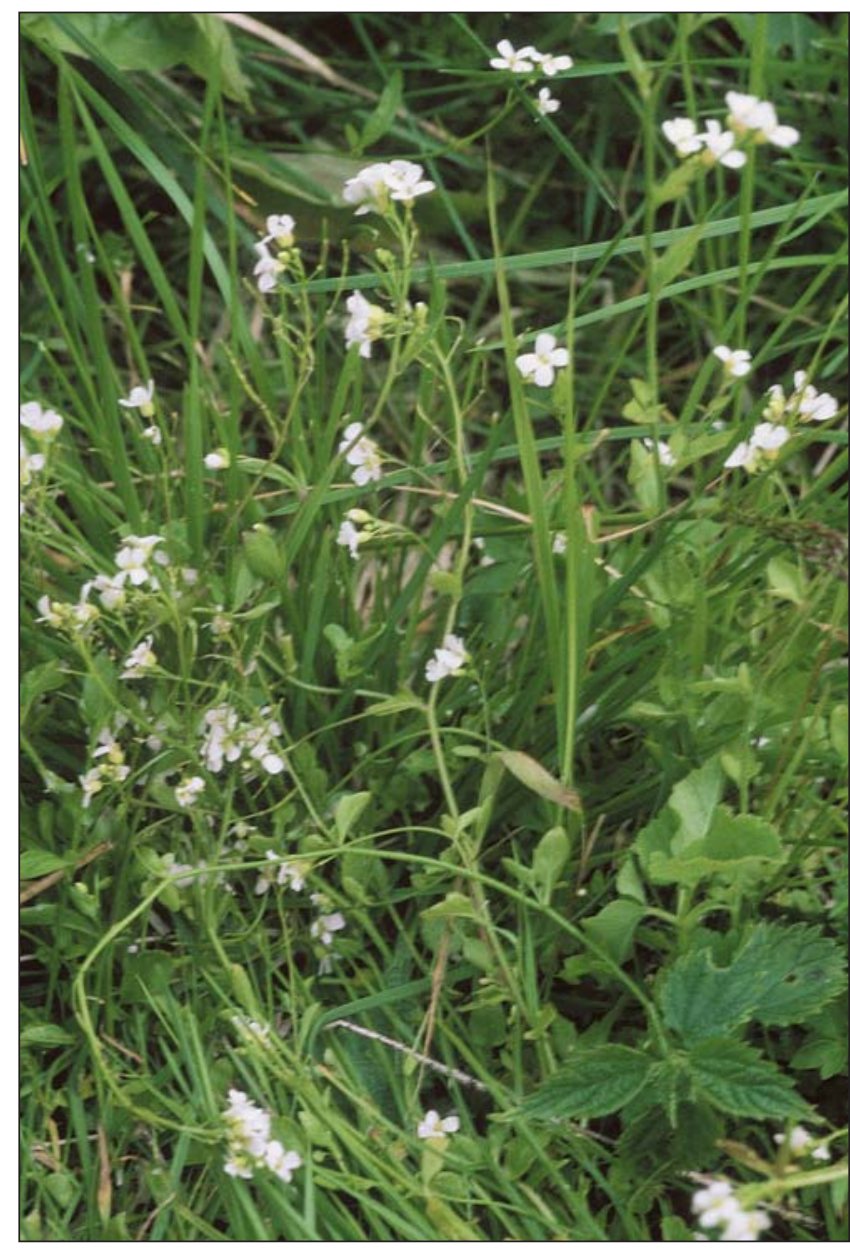

Fig. 4. Arabidopsis halleri.

The aim of the paper is to present five plants known in Lower Silesia, mainly in the Sudety, which recently arouse interest in ecological literature as heavy-metals accumulators. The taxonomical position of the below mentioned "species" in usually confused and differently described by various authors. However, this fact cannot hinder the interest in the discussed taxons from point of view of their capability to accumulate metals, as, most probably, their changeability is the basic factor of existence of populations, which we recognize as metallophytic (Figs 1-5).

\section{RESULTS AND DISCUSSION}

\section{Asplenium onopteris L. var. silesiaca Milde (Fig. 1)}

This variety grows in Poland on a single stand, on serpentine marble in the Ślęża Massif (Przemiłów). Most authors include this variable taxon among the small species of the group A. adiantum-nigrum. Described by Milde (1855) as an endemic variety, it is usually overlooked. Only Reichstein (Hegi 1984) recognizes rather incorrect the taxon position in the Asplenium cuneifolium Viv. group. After many years of uncertainty the stand on serpentine marble has been confirmed and again described by Schweitzer and Polakowski (1994). These authors mentioned also the taxonomic traits distinguishing this fern. The group of the so-called serpentine ferns is usually not numbered among heavy metals accumulators (Brooks 1988). These plants - as chasmophytes occupy usually rocky fissures filled with humus, and avoid the direct influence of the speci- 
TABLE 1. Heavy metal concentrations in aboveground parts of different plant species ( $\mu$ g/g d.w.) $(n=3-4)$.

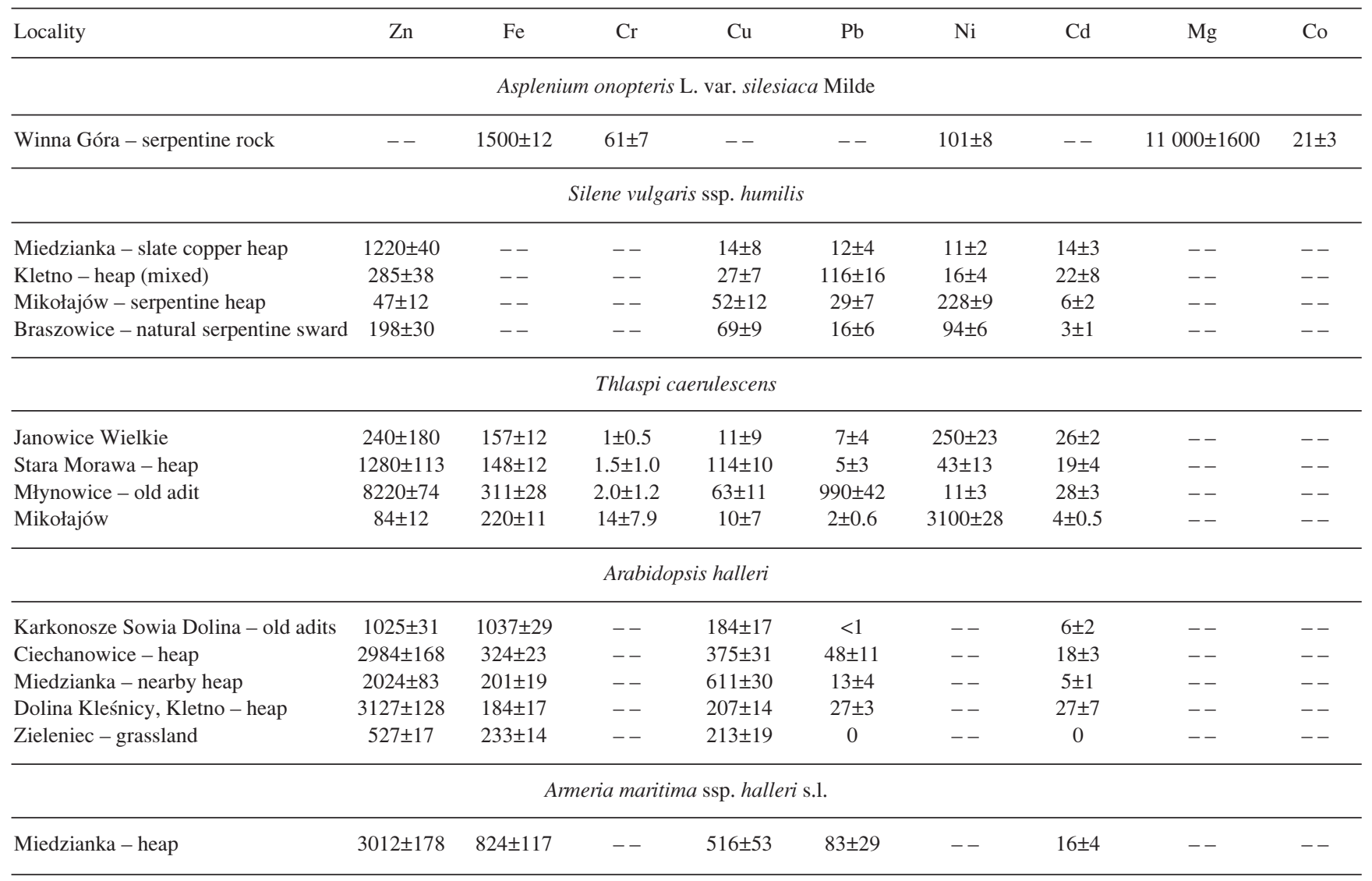

fic, abundant in $\mathrm{Ni}, \mathrm{Cr}, \mathrm{Mg}$ and other metals of serpentine rocks. The contents of heavy metals from one site in the Sudeten are given in Table 1 . The data included in that table approximate the values given for Asplenium adiantumnigrum in Scotland (Johnston and Proctor 1979). Remarkable are there the high contents of $\mathrm{Mg}$ and $\mathrm{Ni}$ - serpentine elements.

In the initial results of analyses and in the remaining fern species growing on serpentine marbles in the Sudeten, higher contents of heavy metals have not been found. Probably, all the local ferns on serpentine habitats developed a strategy of avoiding heavy metals as a resistance mechanism against their overabundance on serpentine soil.

2. Silene vulgaris (Moench) Garcke ssp. humilis

(Schubert) Rauschert (Fig. 2)

It the broad variation of Silene vulgaris, the described subspecies distinguishes itself by many traits, but rather of ecological than morphological character. Generally speaking, it is a taxon of dwarfish size, lying down, frequently creates simply prostrate forms - though also morphologically transient erect forms have been also described. This is more an "ecological" subspecies, occupying terrains abundant in heavy metals, frequent on serpentine soils. Its morphological traits, besides very variable, are described in the third volume of Hegi's Flora (1979) (p. 1096), in Oberdorfer's Flora (1990), and recently - as a variety - by Rothmaler (2002).

In the Sudeten ssp. humilis is a typical subspecies of xerothermic habitats, which occurs on shallow and dry soils. As a natural component of sward it is best known from serpentine habitats, particularly in the Sowie Mts and in the
Ślęża Massif. It makes also an inseparable part of the pioneer vegetation on waste- heaps rich in heavy metals. It covers there various habitats, but prefers flat ledges with consolidated rocky material, as well as more stable, shallow fissures. The taxon under discussion has also been studied by ecologists from various parts of Europe, since the seventies (Ernst 1974) and is recognized as characteristics for the metalophytic - described in the Harz Mts - class Violetea calaminarie (Oberdorfer 1990).

The authors of latest elaborations on problems of heavy metals accumulation and tolerance are: Schat et al. (1996), Ernst and Nelissen (1999), Ernst (2000; 2003). Polish papers on tolerance at cellular and population level in plants belonging to the ssp. humilis were published by Wierzbicka and Rostański (2002). These authors described the most significant traits characterizing the local metalophytic populations. The Sudeten populations, which are contained within the range of forms belonging to the subspecies $h u$ milis, show a wide range of tolerance and accumulation properties towards a lot of elements (Table 1). On copper heaps subsoil (Miedzianka) attention is drawn to the high content of $\mathrm{Zn}(1220 \mathrm{ppm})$ in the analysed plants, and small one - as for the local copper-bearing subsoil - of $\mathrm{Cu}$ (114 ppm). Plants on other stands accumulated considerable amounts of $\mathrm{Pb}$ (Kletno - $116 \mathrm{ppm}$ ). Most interesting are the contents of $\mathrm{Ni}$ in serpentine rocks (up to $228 \mathrm{ppm}$ ), pointing at the restricting part of nickel in shaping succession and the picture of vegetation cover on that substratum. An equivalent importance for plants from serpentine is attributed also to excessive amounts of $\mathrm{Mg}$ (Baker, Proctor, Reeves 1992), revealed in the obtained here results for Asplenium onopteris $(1100 \mathrm{ppm})$ and Silene vulgaris s.1. (228 
ppm). The scattering of the latter data is however so considerable, as evidence of a completely different life strategy in forming a specific serpentine flora.

\section{Thlaspi caerulescens J. Presl et C. Presl (Fig. 3)}

Alpine Penny-cress (family Brassicaceae) and the closely related taxa (e.g. Th. brachypetalum Jordan) are probably the most widely known zinc accumulators, as the capacity to accumulate this metal (up to $2.5 \%$ of dry mass) was known already in the middle of the 19th century (Ernst 1974). The abundant ecological and physiological literature, and recently also molecular investigations devoted to hyperaccumulation in Th. caerulescens, has caused this plant to became a model in laboratory and field investigations (Baker and Whiting 2002).

The unusually fast uptake and accumulation of, not only, zinc by Th. caerulescens specimens (particularly in roots), but also - in other populations - nickel, lead and cadmium, has already been proved (Escarrè et al. 2000).

The taxonomists' approach to the taxonomic rank, separateness and variability of the discussed species are divergent. The discrimination of the many subgenera (e.g., ssp. caerulescens,ssp. calaminare Lej. et Court), and connecting them with metallic habitats contrary to those poor in metals, appeared to be deceptive. Above all, in the distinguished units no genetic separateness (Koch et. al. 1998), as well as no distinct separateness of chemical composition of their habitats' soil was found (Meerts and Van Isacker 1997). The whole complicated synonymy of Th. caerulescens is given in the Flora Europaea (1993), trying to reduce their variability to two subgenera: ssp. caerulescens and ssp. virens (Jordan) Hooker, stating at the some time the wide range of variability and the intricacy in describing the typical subspecies. In the latter edition of the British Flora (Stace 1997) Th. caerulescens has been recognized as an aggregation of the old Th. alpestre L. non Jacq and Th. $c a$ laminare (Lej.) Lej. et Courtis, confirming at the same time, that the variability of Th. caerulescens does not allow to distinguish the taxons of lower rank in a rational way.

Alpine Penny-cress is an annual or a short-lived (2-3 years) perennial plant, in Silesia connected mainly with the Sudeten. Localities situated far in the foreland of the Sudeten (Zgorzelec, Lubań, Kamieniec Ząbkowicki, Paczków), mentioned by former florists, need to be verified. One of the central localities is undoubtedly the upper part of the river Bóbr valley. Joining the remaining localities with the broadly conceived Bóbr valley (from Szklarska Poręba to Bolesławiec), as mentioned by Schube (1903; 1904), is poorly based. We deal here with a local plant, usually occurring in a low number of specimens, in the range of which it is difficult to detect the link-localities. Moreover, many of the localities in the low mountain belt had been destroyed. The range of this plant in the "Bóbr valley" is most likely connected with the old mining of copper, zinc and lead particularly in the surroundings of Janowice Wielkie, Miedzianka and Ciechanowice. The description of its range, strongly connected with the Bóbr valley, omits also the recently found localities of this plant in the Sowie Mts and Bardzkie Mts (Fabiszewski, unpublished), as well as its earlier know presence in the Eastern Sudeten (compare: Brej 2001; Szelagg 2000). According to our observations, Th. caerulescens occur and occurred mainly in areas of the old Sudeten mining industry, and up to-day they "mark" its traces (both mining and anthropogenic ones). Together with excavation of ores, a part of the localities had been destroyed (surroundings of Jelenia Góra and Szklarska Poręba), whereas on respective new localities, more rich in metals, there appeared synanthropic localities (surroundings of Janowice Wielkie). A part of the natural localities is bound with the recently found outcrops of serpentine marbles.

The investigations on concentration of heavy metals in plants coming from various Sudeten localities show a hudge interpopulational differentiation and chemical separateness, adequate for the particular populations. The results of those investigations are illustrated in Table 1.

\section{Arabidopsis halleri (L.) O'Kane \& Al-Shehbaz (Fig. 4)}

This representative of Brassicaceae, previously known as Cardaminopsis halleri (L.) Hayek, was transferred in 1997 to another genus, after other DNA properties have been ascertained. A. halleri has a somewhat more certain taxonomic position than the previously discussed species, though in the latest British Flora (Stace 1997) it is placed among the difficult genus Arabis. In spite of that not very stabile taxonomic position, it is not a plant so commonly known to metal-hyperccumulation students as the Th. caerulescens. The increased degree of tolerance to zinc in several A. halleri populations has been noticed by Fabiszewski (1986). The experiment with the Tatra Mts material was based on laboratory root tests, whereas the contents of heavy metals on excavation heaps, from where the seeds ware taken, was only slightly increased. Nevertheless, the experiment has shown the fixed tolerance to zinc and lack of tolerance for other heavy metals. A. halleri in comparison with the previously described Th. caerulescens, is a perennial, polycarpic plant, with a distinctly marked, longer lasting fructification period, and with capacity for vegetative reproduction. In the Sudety it is a frequent plant on shallow soils, particularly in communities belonging to the Polygono-Trisetion alliance, where it is often accompanied by Agrostis tenuis and Festuca rubra. In spite of the numerous localities of $A$. halleri in the Sudeten, its distribution is irregular. Worthy of notice is its frequency of occurrence on lower situated meadows in the Karkonosze, Bystrzyca Mts, in the Śnieżnik Massif and in the Kamienne Mts; it occurs sparsely in the Izerskie Mts, Stołowe Mts and Bardzkie Mts. Metallophytic populations of Arabidopsis halleri are frequent on ore-bearing territories, particularly among pioneer grasses on stony, gravelly and rubble soils. Though this species is since long known as a metallophyte, growing in communities of the Violetea calaminariae class (Ernst 1976), the details of its physiology and ecological requirements, particularly the uptake and accumulation of metals started to be explained in recent papers (Bert et. al. 2002; Macnair 2002; Baker and Whiting 2002). The cited investigations show a wide chemical and physiological polymorphism of the hyperaccumulator recently examined with great care, the populations of which accumulate in various degree zinc and cadmium in ore-bearing areas, or else, they behave on soils poor in metallic compounds like other wild-growing plants, devoid of accumulation capacity with regard to whichever element.

Table 1, which presents the heavy-metals content in the aboveground parts of the A. halleri collected in various Sudeten localities, shows the increased and differentiated 
contents of heavy metals. In the investigated area A. halleri is a zinc accumulator, but the concentration of this metal exceeds nowhere $10000 \mathrm{ppm}$, that is, the content determined for hyperaccumulators (Baker and Brooks 1989). Likewise, a high variability in accumulation of zinc and other elements in various European localities has been shown by other authors, e.g., in Austria (Wenzel and Jockwer 1999). These authors notify the contents of zinc, as high as 5320 ppm, in representatives of an A. halleri population growing in a contaminated area. The variability of accumulation values for natural and metallophytic populations of Arabidopsis halleri are wider discussed by Bert et al. (2002). The data of our own investigations (Table 1) attest to a wide range of uptake and accumulation of metals by this species and its various populations. In the investigated species no decided capability for metals hyperaccumulation was found, but merely their first signs. The highest metal contents were found in plants from an "uranium" heap in Kletno, where the high content of $\mathrm{Zn}$ is also accompanied by increased concentrations of $\mathrm{Cd}$ and $\mathrm{Pb}$. The accumulation of the mentioned three elements is, so to say, an inborn property of $A$. halleri (Bert et al. 2002). However, as shown by investigations in various European areas, the occurring variability in amount of the accumulated elements attests significantly, that this plant has, on the one hand, a non-fixed taxonomic variability, and on the other, its various "ecotypes" were not yet able to form the typical properties of accumulators for good. In the described area of investigation it was only possible to record a very interesting differentiation in heavy metals accumulation in the five distinguished A. halleri populations from ore-bearing areas. a very interesting differentiation in heavy metal accumulation. This may lead in course of time to hyperaccumulation, typical for the given populations. The data for population no. 5 from Zieleniec, which should be regarded as "non-metallophysic", stray considerably from results obtained from measurements of populations contaminated by heavy metals, as they reach values characteristic for plants from unpolluted areas.

\section{Armeria maritima (Mill.) Willd. ssp. halleri s.l. (Fig. 5)}

In the wide and still unexplained variability of Armeria maritima (family Plumbaginaceae), several varieties (or according to seizure - subspecies), are considered as taxonomic units rated among metallophytes. In Western Europe and in Poland, only the subspecies ssp. halleri s.1. occurs on ore-bearing areas. The taxonomic distinction, mainly by cytological separateness, was performed by A. and D. Löwe, but the found differences were not confirmed morphologically. Hence, this subspecies is usually regarded as a set of various populations exhibiting predilection for occupying areas abundant in heavy metals, and accumulation in tissues, above all zinc and lead, and sometimes also arsenic, copper and cadmium (Ernst 1974; Köhl 1997; Bernard and Lefèbvre 2001; Lefèbvre 1974). In the not very rich ecological literature concerning that collective species and units of lover rank, distinguished are maritime, cliff and serpentine populations, and from among anthropogenic ones - those occurring on various industrial heaps and dumps (Ernst 1982). It is also known (Bernard and. Lefèbvre 2001), that the A. maritima accumulates more zinc and lead in below-ground parts than in leaves. The small number of specimens, which occupy probably the sole locality of this taxon in Lower Silesia (and probably also in Poland), did not allow to perform more comprehensive chemical analyses. Table 1 presents concentrations of selected heavy metals, which confirm the A. maritima capability to accumulate zinc, and also to accumulate considerable amounts of lead. The latter element is accumulated in highest amounts by all the plants described in the present paper.

\section{CONCLUSIONS}

The paper presents five species, which may represent the regional accumulators of heavy metals in Lower Silesia. The species are representatives of different families, of which the two ones belong to Brassicaceae (Thlaspi caerulescens and Arabidopsis halleri), a family known of having wide possibilities to accumulate heave metals. The species Armeria maritima, represents, a separate in this respect, family Plumbaginaceae. The latter is, however, closely related to the family Caryophylaceae (represented here by Silene vulgaris), the numerous species of which show a considerable predilection to excess of most heavy metals (Ernst 2003), Known is e.g. the accumulation capability of many species from genera: Dianthus, Gypsophila, Silene, Viscaria and Minuartia growing in natural ore-bearing terrains, as well as in anthropogenic areas comprising heavy metals.

The results obtained in investigations concerning heavy metals' concentrations in plants are presented in Table 1. The most general conclusion leads to the statement, that the found contents depend in a small degree upon the investigated objects, that is to say, upon the quality of deposits (i.e., the composition of the extractive material), but upon individual traits of plant populations - independent of their species affiliation. This probably results from the important part played by the relation: soil - species population and the mechanisms developed during many years, allowing to accumulate the given element. In the poorly marked effect of soil (objects), conspicuous is the serpentine soil, which in Mikołajów (Table 1) determined the high level of nickel accumulation (3100 ppm), which is not taken up in so high amounts from any other soil, and by the remaining plants investigated. The data included in Table 1 confirm the known thesis on existence of local genotypes (chemoecotypes) in plants - emphasized among others by Fabiszewski (1986), Ernst (2003), Larcher (2003) - evolving towards an increased tolerance for the considerable local presence of metals, irrespective of other populations of the same species. Analyzing the presented table, one can also notice that the populations of the investigated plants show usually in all objects an increased concentration of zinc - up to the record-breaking, in our conditions, amount of $8220 \mathrm{ppm}$ in the locality near the lead mine-tunnel in Młynowiec. More "stabile" and leveled off, in respect of Zn accumulation, are the populations of Arabidopsis halleri. Like in the case of Thlaspi caerulescens from Młynowiec, also the plants of Arabidopsis halleri (Table 1) show an increased accumulation of lead, and frequently cadmium. The old mining and copper-bearing deposits, containing, among others, lead (occurring in the areas of Ciechanów, Janowice Wielkie and Miedzianka), showed almost no plant or accumulation specificity, except of presence of a single, known in Silesia, locality of Armeria maritima in a specific subspecies (ssp. halleri s.1.). However the population of A. maritima 
did not "react" (in the sense of an increased number of specimens) to the considerable presence of copper in soil. This is probably connected with the presence of $\mathrm{Cu}$ in sulphate form, which considerably lowers the acidity of soil (Ernst 2003). The low pH (on the average 3.8), and the dry, permeable soil are probably the main factors responsible for the floristic poverty and the low succession rate in metalbearing areas in Miedzianka and vicinity. The population of A. maritima, as an exception in the poor flora, deserves here close attention and protection. Though it did not develop genetic conditions for accumulation of copper, it is a population resistant to high content of this element in soil, and to the mentioned previously unfavorable ecological conditions created by the local soil.

The most intensively accumulated element by $A$. mariti$m a$, growing on metal-bearing heaps, is zinc, whereas the description of lead and cadmium accumulation does not differ from that, characteristic of the previously discussed species. All these values create a picture of merely an increased accumulation of elements, which exceptionally, only in several of the analyzed cases, signals the creation of hyperaccumulation mechanisms in some of the populations.

It is easy to answer the question, why the Lower Silesian and Sudeten plants did not develop traits typical for hyperaccumulators known from other parts of Europe. Here are undoubtedly acting factors of historical nature, and so the late - because of many reasons - plant succession of metalbearing terrains and their ecological inaccessibility (low $\mathrm{pH}$, permeability and dryness of habitats, and their low supply of macroelements). But the lapse of time acts undoubtedly in favour of origin and fixation of accumulative and genetic mechanisms - so, as happens in case of evolution in general.

Metal-bearing areas belong among those specific terrains, which are characterized by a low biodiversity. This trait does not depreciate them in the eyes of ecologists - quite the reverse - as terrains settled by plants subjected "under our eyes" to microevolutionary processes, and those on which the numerous phenomena of plant adaptation to "extreme" habitat conditions can be easily followed. Those habitats should be protected from destruction.

\section{LITERATURE CITED}

BAKER A.J.M., BROOKS R.R. 1989. Terrestrial higher plants which hyperaccumulate metallic elements - a review of their distribution, ecology and phytochemistry, Biorecovery 1: 81-126.

BAKER A.J.M., PROCTOR J., REEVES R.D. (eds) 1992. The Vegetation of Ultramafic (Serpentine) Soils. Intercept, Andover.

BAKER A.J.M., WHITING S.N. 2002. In search of the Holy Grail - a further step in understanding metal hyperaccumulation? New Phytologist 155: 1-7.

BERNARD C., LEFĖBVRE C. 2001. The Zn biogeochemistry of Armeria maritima (Mill.) Willd.: within and between population studies, Belg. J. Bot. 134: 21-28

BERT V., BONNIN I., SAUMITOU-LAPRADE P., de LAGUÉRIE P., PETIT D. 2002. Do Arabidopsis halleri from nonmetallicolous populations accumulate zinc and cadmium more effectively than those from metallicolous populations? New Phytologist 155: 47-57

BOYD R.S., MARTENS S.N. 1992. The raison d'etre for metal hyperaccumulation by plants. In: Baker J.M., Proctor J., Ree- ves R.D. (eds). The Ecology of Ultramafic (Serpentine) Soils, Intercept, Andover., 279-289 p.

BOYD R.S., MARTENS S.N. 1998. Nickel hyperaccumulation by Thlaspi montanum var. montanum (Brassicaceae): a constitutive trait, Am. J. Bot. 85 (2): 259-265.

BREJ T. 2001. Interesujące gatunki chwastów Masywu Śnieżnika, Gór Bialskich i Gór Złotych. Ann. Silesiae 31: 99-107.

BREJ T., FABISZEWSKI J. Rośliny akumulujące metale ciężkie we florze Sudetów. Ann. Sliesiae 32: 155-163.

BROOKS R.R. 1998. Plants that Hyperaccumulate Heavy Metals. Wallingford, UK: CAB International, $380 \mathrm{pp}$.

ERNST W.H.O. 1974. Schwermetallvegetation der Erde. Gustav Fischer, Stuttgart.

ERNST W.H.O. 1976. Violetea calaminariae R.Tx. 1961. In: Prodrome of the European Plant Communities. Tüxen R. (ed.). J. Cramer, Vaduz, 132 pp.

ERNST W.H.O. 1982. Schwermetallpflanzen. In: Kinzel H. (ed.), Pflanzenökologie und Mineralstoffuechsel, E. Ulmer, Stuttgart, p. 472-506

ERNST W.H.O. 1987. Population differentiation in grassland vegetation. In: Van Andel J., Bakker J., Snaydon R.W. (eds), Disturbance in Grasslands. W. Junk, Dordrecht, p. 213-228.

ERNST W.H.O. 2000. Evolution and ecophysiology of metallophytes in Africa and Europe. In: Breckle S.W., Sweizer B., Arndt U. (eds). Results of Worldwide Ecological Studies. G. Heimback Verlag, Stuttgart, p. 2335.

ERNST W.H.O. 2003a. The use of higher plants as bioindicators. In: Markert B.A., Breure A.M., Zechmeister H.G. (eds). Bioindicators and Biomonitors. Elsevier, Amsterdam, p. 423-463.

ERNST W.H.O. 2003b. Evolution of adaptation mechanisms of plants on metal-enriched soils. In: Larcher W., Physiological Plant Ecology, Springer Verlag, Berlin, p. 433-436.

ERNST W.H.O., NELISSEN H.J.M. 2000. Life-cycle phases of a zinc - and cadmium- resistant ecotype of Silene vulgaris in risk assessment of polymetallic mine soils. Environm. Pollut. 107: 329-338.

ESCARRÈ J., LEFÈBVRE C., GRUBER W., LEBLANC M., LEPART J., RIVIÈRE Y., DELAY B. 2000. Zinc and cadmium hyperaccumulation by Thlaspi caerulescens from metalliferous and nonmetalliferous sites in the Mediterranean area: implications for phytoremediation. New Phytologist 145: 429$-437$.

FABISZEWSKI J. 1986. Heavy metal tolerance of Cardaminopsis halleri (L.) Hayek populations in the Polish Tatra Mts. Acta Soc. Bot. Pol. 55 (3): 421-428.

FABISZEWSKI J., BREJ T., BIELECKI K. 1983. Plant indication on environmental influence of copper smelter. Prace Wrocł. Tow. Nauk., Ser. B 207: 1-110 (in Polish with English summary).

FLORA EUROPEA 1993. Vol. 1. Second Ed. Cambridge Univ. Press, Cambridge, 577 pp.

GODZIK B. 1991. Accumulation of heavy metals in Biscutella laevigata (Cruciferae) as a function of their concentration in substrate. Polish Bot. Stud. 2: 241-246.

GODZIK B. 1993. Heavy metals content in plants from zinc dumps and reference areas. Polish Bot. Stud. 5: 113-132.

JOHNSTON W.J., PROCTOR J. 1979. Ecological studies on Lime Hill serpentine, Scotland. Trans. Bot. Soc. Edinb. 43: 1454-150.

KOCH M., MUMMENHOFF K., HURKA H. 1998. Systematics and evolutionary history of heavy metal tolerant Thlaspi caerulescens in Western Europe: evidence from genetic studies based on isozyme analysis. Biochem. System. Ecol. 26: 823-838 .

KÖHL K. 1997. Do Armeria maritima (Mill.) Willd ecotypes from metalliferous soils and non-metalliferous soils differ in growth response under Zn stress? J. Exp. Bot. 48: 1959-1967.

LARCHER W. 2003. Physiological Plant Ecology. 4th Edition. Springer Verlag, Berlin. 
LEFÈBVRE C. 1974. Population variation and taxonomy in Armeria maritima with special reference to heavy metal tolerant populations. New Physiologist 73: 209-219.

MACNAIR M.R. 2002. Within and between populations genetic variation for zinc accumulation in Arabidopsis halleri. New Physiologist 155: 59-66.

MEERTS P., VAN ISACKER N. 1997. Heavy metal tolerance and accumulation in metallicolous and non-metallicolous populations of Thlaspi caerulescens from continental Europe. Plant Ecol. 133: 221-231.

MILDE J. 1855. Die Kryptogamenflora der umgegend von Breslau. Jahresbericht d. Schlesien. Gesell. f. vaterländ, Kultur 33: 92-95.

OBERDORFER E. 1990. Pflanzensoziologische Exkursionsflora. Verlag Eugen Ulmer, Stuttgart.

ROBERTS B.A., PROCTOR J. 1992 (eds). Ecology of Areas with Serpentinized Rocks - A World View. Geobotany 17. Kluwer Acad. Publ., Dordrecht.

ROTHMALER W. 2002. Exkursionflora von Deutschland. Bd. 4. Spectrum Academischer Verlag, Heidelberg.

SCHAT H.R., VOOIJS R., KUIPER E. 1996. Identical major gene loci for heavy metal tolerances that have independently evolvet in different local populations and subspecies of Silene vulgaris. Evolution 50: 1888-1895.

SCHUBE Th. 1903. Die Verbreitung das Gefässpflanzen in Schlesien. R. Nischkowsky, Breslau.

SCHUBE Th. 1904. Flora von Schlesien preussischen und österreichischen Anteils. Wilh. Gottl. Korn, Breslau.

SCHWEITZER H.-J., POLAKOWSKI B. 1994. Ehemalige und jetzige Verbreitung seltner Gefässpflanyen In West - und Nord - Polen. Senckenbergiana Biol. 73: 189-214.

SHAW A.J. 1990 (ed.). Heavy Metal Tolerance in Plants: Evolutionary Aspects. CRC Press, Boca Raton.

STACE C. 1997. New Flora of the British Isles. Cambridge Univ. Press, Cambridge.

SZELĄG Z. 2000. Rośliny naczyniowe Masywu Śnieżnika i Gór Bialskich. Inst. Bot. im. W. Szafera, PAN, Kraków.

WENZEL W.W., JOCKWER F. 1999. Accumulation of heavy metals in plants grown on mineralized soils in the Austrian Alps. Environm. Pollut. 104: 145-155.

WIERZBICKA M., ROSTAŃSKI A. 2002. Microevolutionary changes in ecotypes of calamine waste heap vegetation near Olkusz, Poland: a rewiev. Acta Biol. Cracov., Ser. Bot. 44: 7-19. 